\title{
Probable advanced hydroid from the Early Ordovician of China
}

\author{
Andrzej Baliński $\cdot$ Yuanlin Sun $\cdot$ Jerzy Dzik
}

Received: 22 August 2012/Accepted: 21 January 2013/Published online: 11 May 2013

(C) The Author(s) 2013. This article is published with open access at Springerlink.com

\begin{abstract}
A fossil of a colonial organism with pyritized soft tissues of elongated fusiform zooids, found in the middle part of the early Floian Fenxiang Formation in Hubei Province of China, probably represents the oldest reliable record of a hydroid cnidarian. The preservation of the fossil is sufficiently different from that of associated carbonized skeletons of graptolites to exclude affinities with this group. The fossil is unlikely to be a bryozoan because of the mode of budding from proximal, not distal, parts of parent zooids, which is typical rather of hydroids. Although no thecae are preserved, the fossil, named Sinobryon elongatum gen. et sp. nov., is suggested to be a thecate hydroid, possibly related to the Haleciidae. The apparent presence of an advanced member of the thecaphoran Macrocolonia clade in strata $470 \mathrm{Ma}$ old means that much of the hydroid (and cnidarian) diversification preceded the Middle Ordovician.
\end{abstract}

Keywords Hydrozoa · Evolution · Fossil · China · Ordovician

\footnotetext{
A. Baliński $(\bowtie) \cdot J$ J. Dzik

Instytut Paleobiologii PAN, Twarda 51/55, 00-818 Warszawa,

Poland

e-mail: balinski@twarda.pan.pl

J. Dzik

e-mail: dzik@twarda.pan.pl

Y. Sun

Key Laboratory of Orogenic Belts and Crustal Evolution,

School of Earth and Space Sciences, Peking University,

Beijing 100871, China

J. Dzik

Instytut Zoologii Uniwersytetu Warszawskiego, Banacha 2, 02-097 Warszawa, Poland
}

Kurzfassung Ein fossilisierter kolonialer Organismus mit pyritisierten Weichteilen aus dem mittleren Teil der Fenxiang Formation (frühes Floium, Hubei Formation, China) stellt wahrscheinlich den ältesten Vertreter der hydroiden Cnidaria dar. Die Erhaltung dieses mutmaßlichen Vertreters der Hydrozoa ist hinreichend verschieden von der kohligen Erhaltung dort ebenfalls vorkommender Graptolithen, um eine Zugehörigkeit zu dieser Gruppe auszuschließen. Das Fossil zeigt einen typisch hydroiden Knospungsmodus, der vom proximalen und nicht vom distalen Teil des Zooids erfolgt. Hierdurch unterscheidet es sich von Bryozoen. Obwohl Thecae nicht erhalten sind, wird vorgeschlagen, das Fossil mit dem Namen S. elongatum gen. et sp. nov. den thecaten Hydrozoen zuzurechnen. Es ist möglicherweise mit den Haleciidae verwandt. Die offenkundige Präsenz eines abgeleiteten Vertreters der Klade Macrocolonia (Thecata) vor 470 Mio a legt nahe, dass die wesentlichen stammesgeschichtlichen Aufspaltungen der Hydrozoa (und Cnidaria) bereits vor dem mittleren Ordovizium stattgefunden haben.

Schlüsselwörter Hydrozoa · Evolution · Fossil · China · Ordovizium

\section{Introduction}

It is popular wisdom that hydras and medusae are among the most primitive of living animals. This is why early students of ancient Ediacaran and Cambrian fossils expected to find them there. It was once customary to classify any fossil of a colonial organism with organic skeleton among the hydrozoans (e.g., Kozłowski 1959). If hydroid polyps are so ancient, their medusa stages (or at least those of phylogenetically more basal cubozoans or 
scyphozoans) would also be represented in coeval strata. Contrary to expectations, there is no conclusive evidence that medusoids with tetraradial symmetry were present in the Ediacaran or Cambrian. The alleged Precambrian medusoids were actually basal discs of problematic frond-like Petalonamae (e.g., Dzik 2002; Young and Hagadorn 2010), whereas those from the Cambrian (Cartwright et al. 2007; Young and Hagadorn 2010) were disc-like skeletons of probable lophophorates Eldonioidea (Dzik 1991; Dzik et al. 1997) or show close similarity to Cambrian ctenophores (e.g., Maotianoascus; Chen and Zhou 1997; Dzik 2002) with their perioral "bulb" resembling an umbrella. Most of the isolated carbonized structures retrieved from Ordovician and Silurian limestones which were once interpreted as fossil hydroid thecae (e.g., Kozłowski 1959; Miller and Williams 1991; Rickards et al. 2001), if not all, are graptolite stolons (Mierzejewski 1986; Mierzejewski and Kulicki 2001). Unlike collagenous fusellar and cortical tissues of the colonial skeleton, secreted with the preoral disc, the stolon of graptolites and extant Rhabdopleura is a cuticular structure covering directly the soft body (Urbanek and Dilly 2000). Such proteinaceous skeletons preserve well (Briggs et al. 1995), being transformed into aliphatic polymers (Gupta et al. 2006), their potential for preservation being much higher than that of chitinous hydroid thecae. Paradoxically, in this way the Hydrozoa, once believed to be a very ancient lineage, are deprived of most of their fossil record.

It is known that hydroids and scyphozoans have a linear mitochondrial DNA, a derived condition with respect to anthozoans, which appear to be more ancient in phylogenetic terms (Bridge et al. 1992). As suggested by molecular phylogenies, domination of the medusa stage is plesiomorphic for the Hydrozoa; apparently trachyline hydroids inherited this state from their cubozoan ancestors (Collins et al. 2008). Moreover, solitary polyps are probably ancestral for the hydrozoans; coloniality as a common phenomenon developed with derivation of the capitate clade (Cartwright and Nawrocki 2010). The capitate hydroids, with two sets of tentacles corresponding to oral and marginal tentacles of medusae, respectively, retain a polyp body plan resembling that of a medusa (Shimizu and Namikawa 2009). All this means that the traditionally understood paraphyletic "scyphozoans" should be next after anthozoans and precede hydrozoans in the fossil record.

The timing of appearance of medusae and colonial hydroids is of much importance in calibration of the metazoan phylogenetic tree. Surprisingly few fossil dates are available for calibration of cnidarian molecular phylogenetic trees, and they may be of low reliability (e.g., five in Park et al. 2012, three in Stolarski et al. 2011). Therefore, any evidence that such fossils are represented in the Early Paleozoic requires close scrutiny. In this paper we critically evaluate a new finding of a possible ancient hydrozoan in the Ordovician of the Three Gorge area of southern China.

\section{Geological setting}

The single specimen described in this paper was collected from the middle part of the Ordovician Fenxiang (transcribed also Fenhsiang) Formation near the Village of Tianjialing. The section lies on the northwest edge of the Huangling Anticline (Fig. 1a), about $8 \mathrm{~km}$ southeast of Xingshan County in the Yichang area (also known as the Three Gorge area) of Hubei Province (southern China). It consists mainly of dark-grey to grey skeletal and peloidal limestone and greenish-grey shale, about $40-50 \mathrm{~m}$ thick in the east and about $20 \mathrm{~m}$ thick in the west of the anticline (Fig. 1). In the Tianjialing section, the formation attains about $10 \mathrm{~m}$ in thickness (Fig. 1b) and yields rather sparse, usually very fragmented fossils, although exceptionally a few specimens preserving soft body or organic skeleton were also found. Bryozoans, trilobites, and benthic graptolites (Acanthograptus and Koremograptus) are the most common. In acid-resistant residues of limy intercalations, phosphatized antipatharian corals are abundant; brachiopods, conodonts, and phosphatized remnants of arthropods are less numerous to very rare. The conodonts indicate an earliest Floian (Arenig) age for the strata (Baliński et al. 2012). The hydroid specimen described in this report and a few specimens of linguloid brachiopods preserving soft parts with remarkable fidelity (Baliński and Sun 2013) were collected from a single, few-centimeter-thick bed of greenish-grey shale.

\section{Preservation of the specimen}

The fossil from the Fenxiang Formation is discernible on the surface of shale due to the color distinction between the stem and zooids and their background (Fig. 2). As visible under a scanning electron microscope (Fig. 3g, h), it consists of tightly packed spherical framboids, which implies that the original mineral was pyrite $\left(\mathrm{FeS}_{2}\right)$. Elemental analysis of framboids in the studied specimens from the Fenxiang Formation shows a concentration of iron but no signal for sulfur. Other mapped elements (silicon, aluminum, potassium, and magnesium) are mostly associated with the background and are characteristic for clay minerals. The total absence of sulfur can be explained by secondary oxidation of the original pyrite.

Although pyrite is ubiquitous in marine sediments, it is rarely responsible for preservation of soft parts. Pyritization of soft tissue requires exceptional physical and 

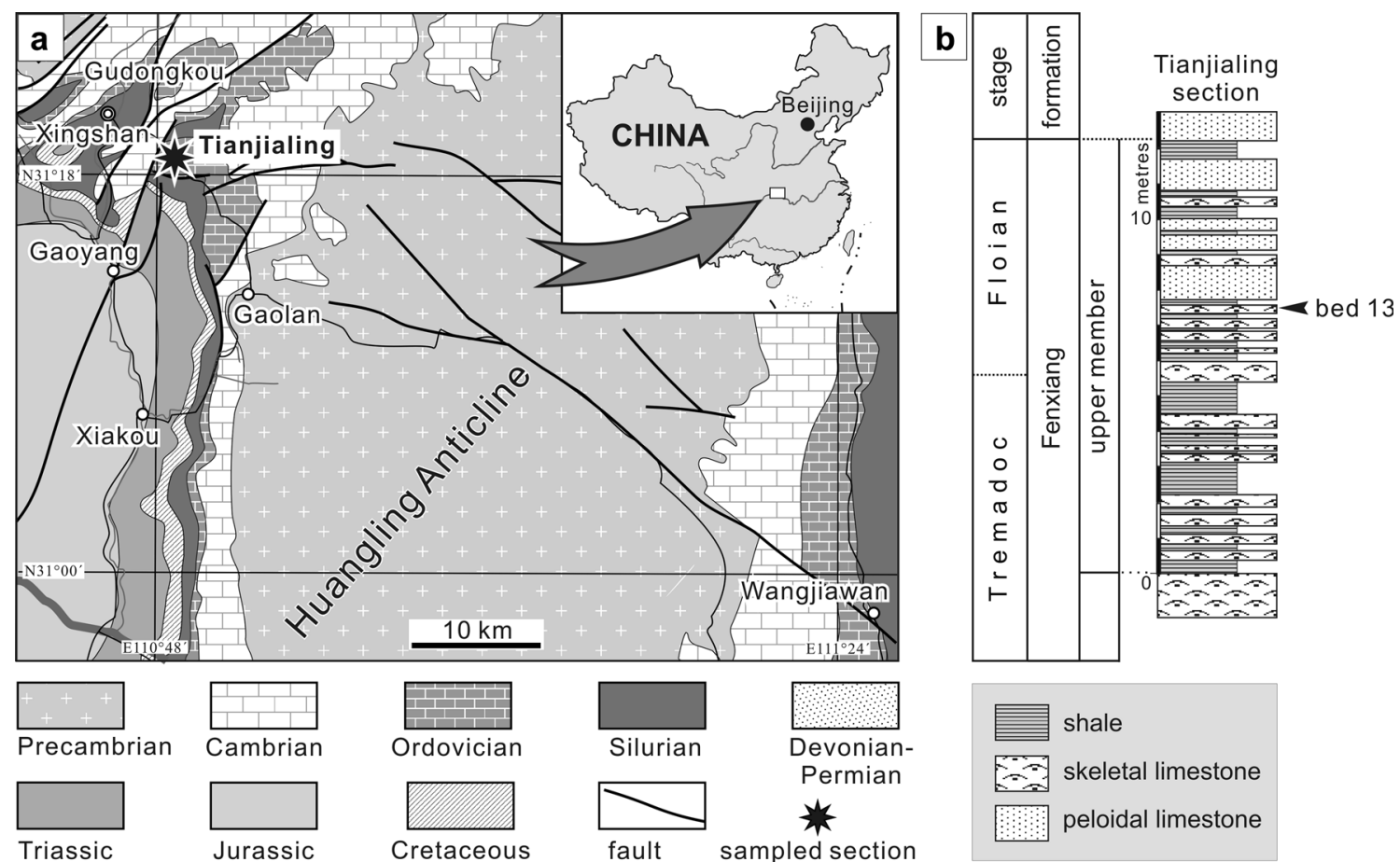

Fig. 1 Location of the Tianjialing section in the Three Gorge area of Hubei Province, southern China. a Geological map. b Rock column of the Fenxiang Formation with the source level of the hydroid specimen indicated

chemical sedimentary conditions paired with rapid burial (Allison and Briggs 1991).

The soft tissues of the Fenxiang hydroid were pyritized throughout their whole volume and subsequently somewhat flattened by sediment compaction. No remnant of the original organic matter is preserved, although the associated, originally collagenous graptolite rhabdosomes are perfectly preserved as black carbonized structures (transformed into aliphatic polymers; Gupta and Summons 2007).

\section{Morphology of the colony}

The only specimen is preserved as a part and counterpart about $50 \mathrm{~mm}$ tall. The attachment of the colony is missing. The stolons and zooids were probably originally circular in cross-section (Fig. 3g).

When data from the part and counterpart are superimposed on each other (Fig. 2), 13 lateral branches from a main stem are revealed. The points of branching are not quite clear, but the distance between them can be estimated as approximately $3 \mathrm{~mm}$. The axial stem is slightly zigzagged, resulting from branching. It is $0.5 \mathrm{~mm}$ thick at the base and $0.32 \mathrm{~mm}$ in its upper part. The lateral branches arise from the sides of the axis and are preserved on various bedding planes, suggesting that the stem branched radially and the regularly spaced branches were probably arranged helically. The branches are almost perfectly straight except for their attachments to the axis, to which they are inclined at a slightly more acute angle. They attain $0.12-0.18 \mathrm{~mm}$ in width and are inclined at about $23-40^{\circ}$ to the main stem. Only lateral branches bear zooids that developed only on their upper (distal) sides about $2 \mathrm{~mm}$ apart.

The zooids arise uniserially at a very acute angle to the lateral branches (Figs. 2, 3). They are rather sparsely distributed on the upper (distal) surface of the branches ( 2 zooids per $5 \mathrm{~mm}$ ); up to five zooids have been observed on a single branch. They are up to $2.2-2.75 \mathrm{~mm}$ long, slender, cylindrical, markedly elongated, and about 7.5-12.5 times longer than wide. When filled with (oxidized) pyrite, they vary in width from 0.16 to $0.20 \mathrm{~mm}$, but those preserved as imprints are strongly compressed, attaining about $0.3 \mathrm{~mm}$ in width.

\section{Morphology of zooids}

There is no evidence of any separate skeleton surrounding the zooids. Apparently, only remnants of the soft tissues of the "stolons" and "zooids" were sites of iron sulfide precipitation and its eventual transformation into crystalline framboidal pyrite.

The pyritized bases of the zooids are in continuity with the colony branch from which they arise. They are virtually parallel to the colony branches for most of their length. The most completely preserved zooid is $2.75 \mathrm{~mm}$ long. Its 


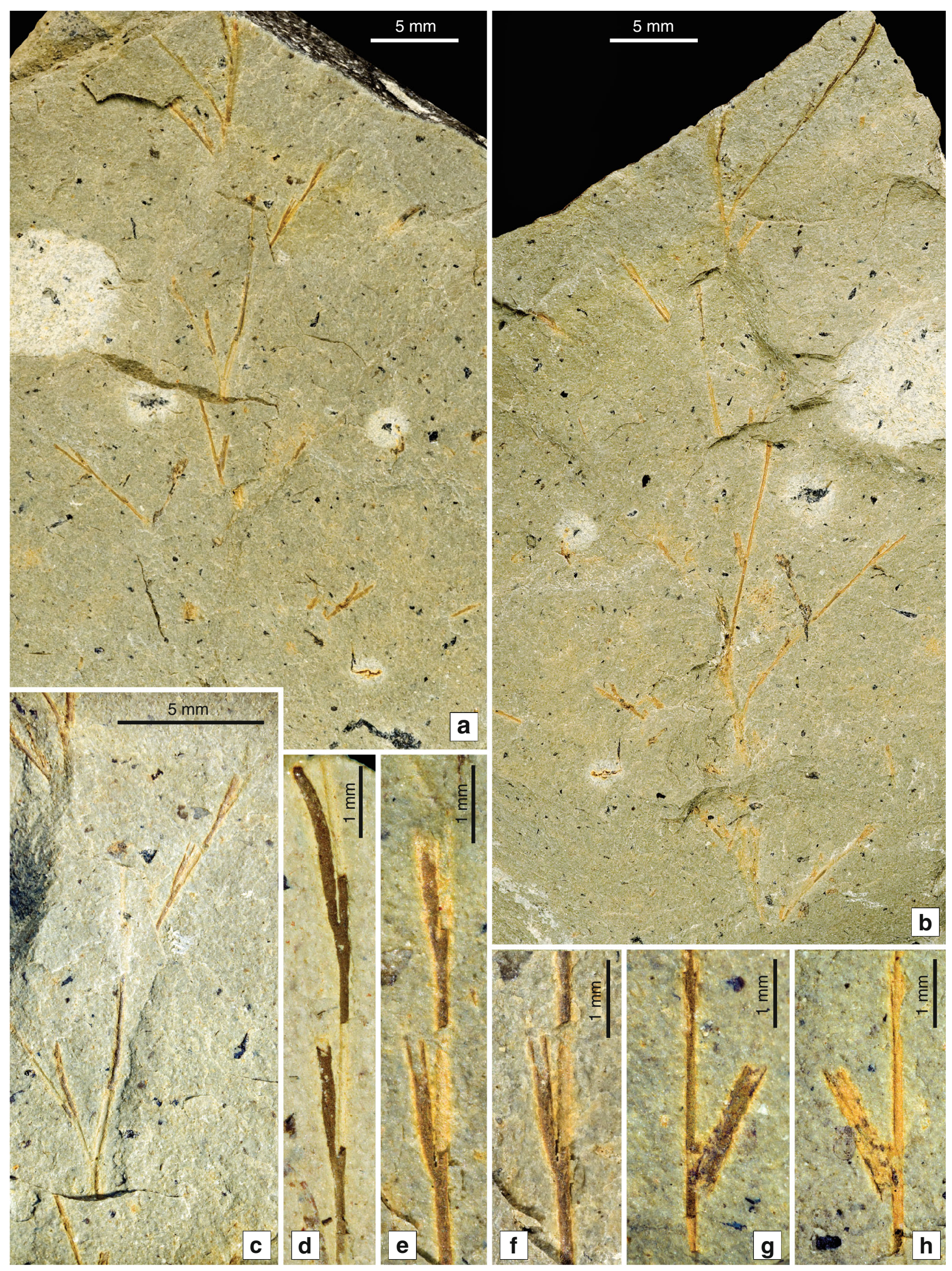


4 Fig. 2 Sinobryon elongatum, gen. et sp. nov., holotype ZPAL Hz 4/1a, b from bed 13, Fenxiang Formation, early Floian, Tianjialing section, Hubei Province, China. a, b Part and counterpart showing general form of the colony and style of branching. $\mathbf{c}$ Enlargements of the part showing relatively well-preserved zooids; note their elongation and infilling with partially oxidized pyrite (brown). d-h Enlargements of hydrothecae. $\mathbf{e}, \mathbf{g}, \mathbf{h}$ Specimens immersed in water

appearance is slightly fusiform, somewhat narrower near the distal end, which is gently curved, departing from the axis (Fig. 3b-f). Its aperture is poorly preserved but seems to be transverse, without recognizable modifications. Another zooid of similar shape is $2.12 \mathrm{~mm}$ long, but its aperture is broken.

\section{Inferred pattern of budding}

Apparently, the colony branches were arranged helicoidally, emerging from the stem at its slight angular bends. Presumably a signal to develop a lateral bud was connected with bending of the preceding zooid (or permanently immature stolonal main axis) in a way similar to that observed in extant ramose hydroids (Kossevitch 2002; Kossevitch et al. 2001). The arrangement of zooids only on the upper side of lateral branches seems to be a plesiomorphic trait in the erect hydroid colonies (Kosevich 2008). However, a vertical orientation of individuals bearing perioral tentacular apparatus is a prerequisite of
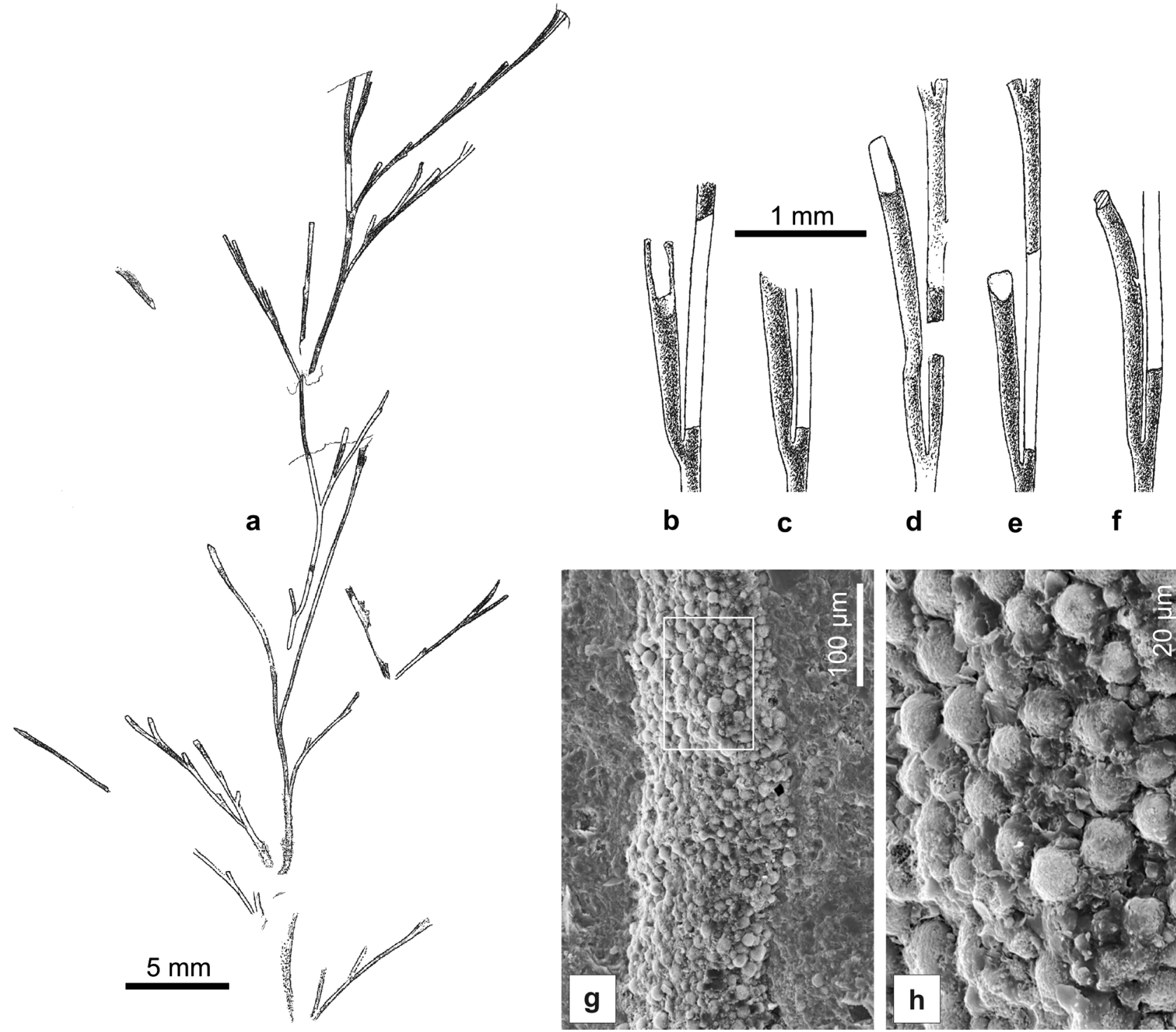

Fig. 3 Sinobryon elongatum, gen. et sp. nov., holotype ZPAL Hz 4/1a, b. a Superimposed camera lucida drawings of part and counterpart (reversed) to show complete set of preserved branches.

b-f Best preserved zooids. $\mathbf{g}$, h SEM pictures of a zooid showing oxidized pyrite framboids that replaced the soft tissue 
proper filtratory action. One may expect that such a pattern develops under selective pressure in any colonial organism, irrespective of whether its tentacular apparatus is armed with nematocysts (cnidarians) or only with cilia (lophophorates). This alone cannot be used in search for relatives of the Fenxiang colony.

The helical organization of the colony suggests that the animal lived in a rather homogeneous environment without stable directional water currents.

\section{Possible zoological affinities}

The Fenxiang hydroid-like colony is associated in the same rock slab with well-preserved graptolite rhabdosomes, including siculae of planktonic dichograptids. They are well carbonized, black and glossy, and of a texture completely different from that of the fossil under study. The lack of a preserved organic skeleton excludes any possibility of their affinity. The graptolite Mastigograptus, which is morphologically closest to the Fenxiang fossil, is characterized by heavily carbonized stolothecae (Andres 1961; Bates and Urbanek 2002; Bates et al. 2009), unlikely to be not preserved in taphonomic conditions suitable for other graptolites. Moreover, the stipes of the Mastigograptus rhabdosome consist of chains of stolothecae with alternately disposed thecal bases of triads (Bates and Urbanek 2002), whereas in Sinobryon elongatum gen. et sp. nov. the zooids arise uniserially on the upper surface of the branches.

The Fenxiang Formation abounds in bryozoans, and a tempting alternative is that the studied colony represents a bryozoan. Bryozoans were already diverse in the earliest Floian (Arenig), forming reefal bodies of the Fenxiang Formation (e.g., Adachi et al. 2011, 2012) and forming communities with highly derived anatomies in the Baltic region (e.g., Pushkin and Popov 1999; Koromyslova 2009). Among members of those early faunas were also bryozoans with erect uniserial colonies (e.g., the corynotrypid stenolaemate Wolinella, Dzik 1981; cf. also the Late Ordovician Schallreuterella, Hillmer 1987) or lacking mineral skeleton and penetrating calcareous substrate (ctenostomes; Wilson and Palmer 2006). The main difference between the Fenxiang colony and erect bryozoans is their pattern of budding. In the underived stenolaemate bryozoans, buds emerge directly from the distal region of mother zooid, not from its base. This is why we find a bryozoan affinity for the Chinese fossil unlikely. Partially erect colonies with chitinous skeleton characterize some extant ctenostomes (e.g., Bowerbankia), but their branches are differentiated stolons bearing clusters of zooids and show different patterns of budding.

Yet another possibility that has to be considered is an algal nature for the Fenxiang fossil. The main argument that can be used to refute any plant affinities is the apparent stiffness of branches and regular appearance of the whole specimen. Such regularity rarely develops in marine plants. No adaptations to increase the surface area of branches to promote photosynthesis are expressed in the morphology of the fossil. Also, pyritization of the stem and probable zooids is not a phenomenon typical for algal fossils, which are generally not as rich in easily decaying organic matter as are animal bodies. This is hardly strong evidence, but we find it sufficient to reject the possibility of a plant origin for the fossil.

An algal affinity has been recently suggested for the celebrated late Devonian "hydroid" Plumalina (Muscente 2011). Fossils of a shape similar to Plumalina are known from the Silurian (Taylor and Griffing 1996) and Ordovician (Webbyites: Kraft et al. 2001; Pennalina: Cope 2005). Only in Webbyites rokycanensis (Bouček 1934) are details of the morphology of possible thecae available (Kraft et al. 2001), and they resemble graptolites rather than hydroids. Whether this can be extended to all Plumalina-like Paleozoic fossils is unknown.

The most likely alternative remains thus a hydroid affinity for the Fenxiang colony. If so, this is a rather advanced form. As already pointed out above, molecular phylogenetic data show that the most basal hydroids were probably solitary (Cartwright and Nawrocki 2010). Coloniality first developed with origin of the capitate clade. Among these, the extant Halocordyle has an erect feathery colony with a strong, somewhat undulose stem and lateral branches bearing regularly distributed zooids. Capitate zooids are of fusiform shape, which agrees with the studied specimen. Although there are no signs of possible tentacles in the Ordovician fossil, they could have been retracted before burial and/or located near the zooid tips. A capitate affinity for the Fenxiang colony would date the oldest known occurrence of this relatively basal hydrozoan lineage.

The lack of preserved chitinous thecae in the Fenxiang fossil does not, however, contradict its much more advanced thecaphoran nature. Hydroid thecae are built of chitin (Mali et al. 2004; Tretenichenko et al. 2006). Structural chitin does not preserve in older rocks (Gupta and Summons 2007), although in appropriate sedimentary and diagenetic conditions chitin may transform into aliphatic hydrocarbon compounds (Gupta and Summons 2007).

According to molecular phylogenetic evidence, thecate hydrozoans are the most advanced of the class. Erect and branched colony shape is a derived character, being typical for the lineages located high on the tree (Leclère et al. 2009), with the exception of the Lafoeidae, which probably evolved such colony organization independently. Among thecate hydroids having erect and branched colonies and lacking free medusae, the most basal lineage is Haleciidae, 
characterized by short chitinous thecae that do not cover the zooids completely. It is possible that the Fenxiang fossil is a haleciid with incipient thecae that have not fossilized because of taphonomic reasons.

If this interpretation is correct, similarity in the overall colony shape and distribution of thecae of Pontifennia gracilis Cope 2005, from the Early Ordovician of Wales (Cope 2005), would be an expression of evolutionary proximity despite the presence of probable thecae in this fossil. The original or even early diagenetic composition (phosphate?) of the fossilized tissue of the Welsh specimen remains unknown. The probable thecae are completely flattened. They are wider than the pyritized polyps in the Chinese fossil, but the difference in proportions does not preclude the possibility that these are polyps, too. However, the triangular shape and transverse distal ends are suggestive of thecate (possibly graptolite) nature of the fossil. On the other hand, some hydroids might show diverse hydranth forms (see the bioimmured probable hydroids from the Cincinnatian in Wilson et al. (1994).

\section{Hydrozoan fossil record}

Although there are many reports on alleged Cambrian and Ordovician medusae (reviewed in Young and Hagadorn 2010), the oldest truly convincing material comes from the Late Carboniferous Mazon Creek fauna (Johnson and Richardson 1968; Ossian 1973; Foster 1979). "Medusina" atava (Pohlig 1892) from the Early Permian lacustrine strata of Thuringia (Müller 1978) and Progonionemus vogesiacus Grauvogel and Gall 1962 from the Middle Triassic (Anisian) Grès à Voltzia of France (Grauvogel and Gall 1962) are the oldest known limnomedusan hydrozoans (probably Olindiidae). Tarracodiscus villalthai Romero et al. 2011 from the Middle Triassic (Ladinian) MontralAlcover locality in Catalonia was classified in the leptomedusan (that is relatively basal thecate) Aequoreidae by Romero et al. (2011). Hydrozoan medusae are well represented in the Late Jurassic lithographic limestone of Bavaria (e.g., Kolb 1951).

A possible pyritized solitary hydroid has been recently reported from the Late Ordovician (Sandbian) Llanfawr Mudstone of Wales (Boting et al. 2011). An equally problematic record of a solitary polyp is the 15-mm-long Mazohydra megabertha Schram and Nitecki 1975, from the Late Carboniferous (Westphalian) Mazon Creek fauna (Schram and Nitecki 1975).

The oldest reliable fossil hydrozoan has been found preserved by bioimmuration-enclosure under a skeleton of another organism overgrowing the same substrate that results in a natural mold on its basal surface. Such an imprint on the basal surface of a bryozoan colony encrusting a cephalopod conch is known from the Late Ordovician Bellevue Beds of Kentucky. Its "preservation suggests that these organisms were almost entirely covered in a thin, flexible periderm" (Wilson et al. 1994, p. 269). Particular individuals emerged from anastomosing stolons with stems that seem to be proximally annulated. Because of a nipple-like termination of polyps, affinities with the thecate family Campanulariidae were suggested.

A few bioimmured probable thecaphoran hydroids are known from the Late Cretaceous (Voigt 1973; Taylor 1988; Jarms and Voigt 1994; a calcareous stenolaemate bryozoan colony was probably misinterpreted as a bioimmurated hydroid by Waggoner and Langer 1993).

Stolons and zooids preserved as empty cavities (originally submerged) within serpulid polychaete calcareous tubes are known beginning in the Middle Jurassic as Protulophila gestroi (Scrutton 1975; Zágoršek et al. 2009). Today such symbiosis with sabellids characterizes species of Proboscidactyla, a filiferan with only two oral tentacles. Strongly bilateral symmetry of apertures in the Jurassic fossils favors such phylogenetic relationship.

If the Fenxiang fossil is a hydrozoan with affinities to Haleciidae, it represents a highly derived member of the class, and this implies that most of the hydrozoan evolution preceded the Floian (Fig. 4). Nevertheless, erect colonies have evolved independently many times in various clonal suspension-feeders and sessile predators (not only advanced thecate hydroids). Although the hydroid affinity of the Chinese specimen is likely, its precise location on the phylogenetic tree remains disputable.

\section{Taxonomy}

Class Hydrozoa Owen, 1843.

Subclass Hydroidolina Collins, 2000.

Type species: Sinobryon, gen. nov.

Sinobryon elongatum sp. nov.

Diagnosis: Erect, weakly monopodial colony with helically(?) arranged lateral branches covered with one row of regularly distributed, elongated, fusiform polyps.

Etymology: Latin Sinae means Chinese, Greek bryon is a moss.

Remarks: See remarks for the type species.

Sinobryon elongatum sp. nov. (Figs. 1, 2).

Material Holotype, ZPAL $\mathrm{Hz} 4 / 1 \mathrm{a}, \mathrm{b}$ (part and counterpart).

Diagnosis Same as for the genus (by monotypy). 
Fig. 4 Molecular phylogenetic relationships of the main cnidarian lineages (taken from Collins et al. 2006; simplified) and the fossil record of their evolution, with the positions of the Ordovician thecaphorans marked with asterisks. Shading indicates reliable fossil records; outline indicates records of disputable meaning. Note that, in both the paraphyletic "scyphozoan" s.l. and hydrozoan clades, the polyp stage dominates in the lifecycle of the most basal groups (Stauromedusae and Capitata, respectively). In both phylogeny and the fossil record, medusa appears to be a rather late invention

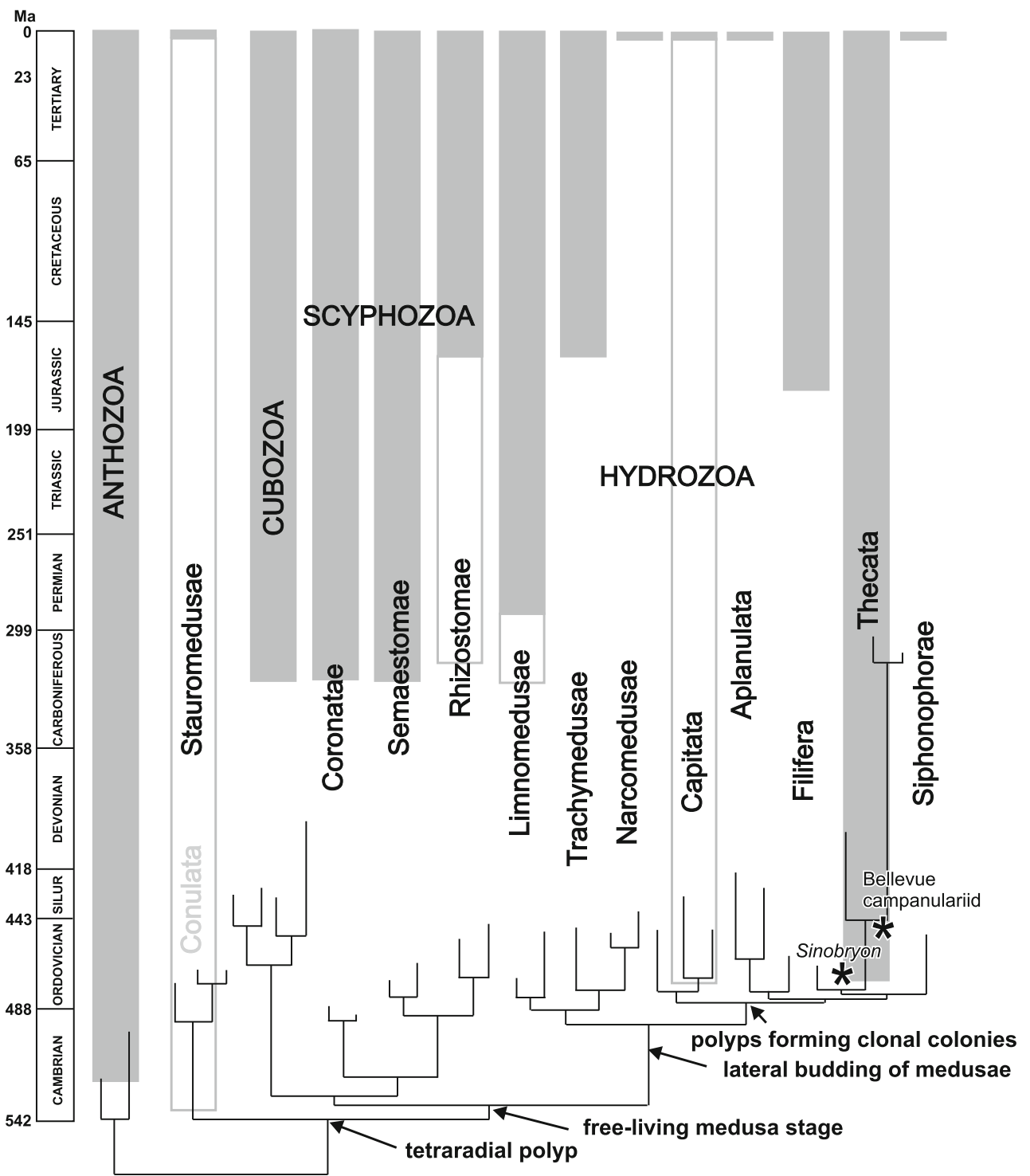

Remarks The new hydroid is similar to Pontifennia gracilis Cope 2005 from the Arenig Series at Pont-yFenni Quarry, Whitland, Carmarthenshire, Wales (Cope 2005), in size and growth pattern. In both species the zooids arise uniserially on the upper surfaces of the branches. In the new genus and species the axis is only slightly thicker than the lateral branches and of sinusoidal course, whereas in P. gracilis the axis is straight and thick. Despite some variation in the angle of branching, the colony of Pontifennia seems to be pinnate, not helicoidal. The zooids of $S$. elongatum gen. et sp. nov. are sparsely distributed along the branches and, even if their preservation is different (zooids instead of thecae), they were much longer and more slender. The main difference between Pontifennia and Sinobryon, which is the elaborate calycal thecae in the former, may be preservational. The Chinese specimen is an almost three-dimensional pyritic replica of the body, whereas the Welsh specimen seems to represent a secondarily mineralized chitinous skeleton, flattened in shale. Presumably, the fossilization history of the latter was complex and the present composition of the fossil is a result of late diagenetic alteration. It has to be kept in mind that Pontifennia may be a sedentary graptolite, as suggested by its similarity to the coeval Webbyites. To determine the true affinities of these two fossils, specimens with structurally preserved organic skeletons are needed.

Acknowledgments SEM pictures and EDS measurements were taken at the Institute of Paleobiology of the Polish Academy of Sciences in Warsaw. Anna Kozłowska (Institute of Paleobiology, Warsaw) determined graptolites co-occurring in the sample. We thank the reviewers Paul Taylor (Natural History Museum, London) and Petr Kraft (Charles University, Praha) for their constrictive criticism and Alexander Nützel (Bavarian State Collection, Munich) for translating the abstract into German. The research was funded by the Polish Ministry of Science and Higher Education, project N N307 130537 to A.B. 
Open Access This article is distributed under the terms of the Creative Commons Attribution License which permits any use, distribution, and reproduction in any medium, provided the original author(s) and the source are credited.

\section{References}

Adachi, N., Y. Ezaki, and J. Liu. 2011. Early Ordovician shift in reef construction from microbial to metazoan reefs. Palaios 26: 106-114.

Adachi, N., Y. Ezaki, and J. Liu. 2012. The oldest bryozoan reefs: A unique early ordovician skeletal framework construction. Lethaia 45: 14-23.

Allison, P.A., and D.E.G. Briggs. 1991. The taphonomy of softbodied animals. In Fossilization: The process of taphonomy, ed. S.K. Donovan, 120-140. London: Belhaven.

Andres, D. 1961. Die Strukur von Mastigograptiden aus einem ordovizischen Geschiebe Berlins. Neues Jahrbuch für Geologie und Paläontologie, Monatshefte 636-647.

Baliński, A., Y. Sun, and J. Dzik. 2012. 470 million years old black corals from China. Naturwissenschaften 99: 645-653.

Baliński, A., and Y. Sun. 2013. Preservation of soft tissues in an Ordovician linguloid brachiopod from China. Acta Palaeontologica Polonica 58: 115-120.

Bates, D.E.B., A. Kozłowska, D. Loydell, A. Urbanek, and S. Wade. 2009. Ultrastructural observations on some dendroid and graptoloid graptolites and on Mastigograptus. Bulletin of Geosciences 84: 21-26.

Bates, D.E.B., and A. Urbanek. 2002. The ultrastructure, development and systematic position of Mastigograptus Ruedemann, 1908 (Graptolithina, Hemichordata). Acta Palaeontologica Polonica 47: 445-458.

Botting, J.P., L.A. Muir, M.D. Sutton, and T. Barnie. 2011. Welsh gold: A new exceptionally preserved pyritized Ordovician biota. Geology 39: 879-882.

Bridge, D., C.W. Cunningham, B. Schierwater, R. DeSale, and L.W. Buss. 1992. Class-level relationships in the phylum Cnidaria: Evidence from mitochondrial genome structure. Proceedings of the National Academy of Sciences of the USA 89: 8750-8753.

Briggs, D.E.G., A.J. Kear, M. Baas, J.W. De Leeuw, and S. Rigby. 1995. Decay and composition of the hemichordate Rhabdopleura: Implications for the taphonomy of graptolites. Lethaia 28: $15-23$.

Cartwright, P., S.L. Halgedahl, J.R. Hendricks, R.D. Jarrard, A.C. Marques, A.G. Collins, and B.S. Lieberman. 2007. Exceptionally preserved jellyfishes from the middle Cambrian. PLoS ONE 2(10): e1121. doi:10.1371/journal.pone.0001121.

Cartwright, P., and A.M. Nawrocki. 2010. Character evolution in Hydrozoa (phylum Cnidaria). Integrative and Comparative Biology 50: 456-472.

Chen, J., and G. Zhou. 1997. Biology of the Chengjiang fauna. Bulletin of the National Museum of Natural Science 10: 11-105.

Collins, A.G., B. Bentlage, A. Lindner, D. Lindsay, S.H.D. Haddock, G. Jarms, J.L. Norenburg, T. Jankowski, and P. Cartwright. 2008. Phylogenetics of Trachylina (Cnidaria: hydrozoa) with new insights on the evolution of some problematical taxa. Journal of the Marine Biological Association of the United Kingdom 88: 1673-1685.

Collins, A.G., P. Schuchert, A.C. Marques, T. Jankowski, M. Medina, and B. Schierwater. 2006. Medusozoan phylogeny and character evolution clarified by new large and small subunit rDNA data and an assessment of the utility of phylogenetic mixture models. Systematic Biology 55: 97-115.
Cope, J.C.W. 2005. Octocorallian and hydroid fossils from the Lower Ordovician of Wales. Palaeontology 48: 433-445.

Dzik, J. 1981. Evolutionary relationships of Early Palaeozoic 'cyclostomatous' Bryozoa. Palaeontology 24: 827-861.

Dzik, J. 1991. Is fossil evidence consistent with traditional views of the early Metazoan phylogeny? In The Early Evolution of Metazoa and Significance of Problematic Taxa, ed. S. Conway Morris, and A. Simonetta, 47-56. Cambridge: Cambridge University Press.

Dzik, J. 2002. Possible ctenophoran affinities of the Precambrian "sea-pen" Rangea. Journal of Morphology 252: 315-334.

Dzik, J., Y. Zhao, and Zhu Maoyan. 1997. Mode of life of the Middle Cambrian eldonioid lophophorate Rotadiscus. Palaeontology 40: 385-396.

Foster, M.W. 1979. Soft-bodied coelenterates in the Pennsylvanian of Illinois. In Mazon Creek Fossils, ed. M.H. Nitecki, 191-267. New York: Academic.

Grauvogel, L., and J.C. Gall. 1962. Progonionemus vogesiacus nov. gen. nov. sp., une méduse du Grès à Voltzia des Vosges Septentrionales. Bulletin de la Service Carte géologique Alsace et Lorraine 15(2): 17-27.

Gupta, N.S., D.E.G. Briggs, and R.D. Pancost. 2006. Molecular taphonomy of graptolites. Journal of the Geological Society 163: 897-900.

Gupta, N.S., and R.E. Summons. 2007. Fate of chitinous organisms in the Geosphere. In Chitin: Formation and diagenesis, ed. N.S. Gupta, 134-151. Dordrecht: Springer.

Hillmer, G. 1987. Schallreuterella syltensis n.g. n.sp., eine cheilostomata-ähnliche Bryozoe aus Öjlemyrflint-Gechieben von Sylt (ob. Ordoviz). In Fossilien von Sylt I, ed. U. von Hacht, 141-147. Hamburg: U. von Hacht.

Jarms, G., and E. Voigt. 1994. Filelloides cretacea n.g. nsp., ein durch Bioimmuration überlieferter Vertreter der Ordnung Hydroida (Hydrozoa) aus dem Maastrichter Tuffkreide (Obermaastrichtium). Paläontologische Zeitschrift 68: 211-221.

Johnson, R.G., and E.S. Richardson. 1968. The Essex Fauna and medusae. Fieldiana Geology 12: 109-115.

Kolb, A. 1951. Hydrocraspedota mayri n. g. n. sp., eine Hydromeduse aus den Plattenkalken von Pfalzpaint. Geologische Blätter für Nordost-Bayern 1: 113-127.

Koromyslova, A.V. 2009. Bryozoans of the Latorp and Volkhov horizons (Lower-Middle Ordovician) of the Leningrad Region. Paleontological Journal 45: 887-980.

Kosevich, I.A. 2006. Branching in colonial hydroids. In Branching Morphogenesis, ed. J.A. Davis, 91-112. Georgetown: Landes Bioscience.

Kosevich, I.A. 2008. Decoding the morphogenetic evolution of thecate hydroids. Journal of the Marine Biological Association of the UK 88: 1687-1694.

Kossevitch, I.A. 2002. Role of the skeleton in determination of the branching points in hydroid colonies. Zhurnal Obshchei Biologii 63: 40-49.

Kossevitch, I.A., K. Herrmann, and S. Berking. 2001. Shaping of colony elements in Laomedea flexuosa Hinks (Hydrozoa, Thecaphora) includes a temporal and spatial control of skeleton hardening. Biological Bulletin 201: 417-423.

Kozłowski, R. 1959. Les Hydroides ordoviciens à squelette chitineux. Acta Palaeontologica Polonica 4: 209-271.

Kraft, P., J. Kraft, and R. Prokop. 2001. A possible hydroid from the Lower and Middle Ordocvician of Bohemia. Alcheringa 25: 143-154.

Leclère, L., P. Schuchert, C. Cruaud, A. Couloux, and M. Manuel. 2009. Molecular phylogenetics of Thecata (Hydrozoa, Cnidaria) reveals long-term maintenance of life history traits despite high frequency of recent character changes. Systematic Biology 58: 509-526. 
Mali, B., F. Mohrlen, M. Frohme, and U. Frank. 2004. A putative double role of a chitinase in a cnidarian: pattern formation and immunity. Developmental and Comparative Immunology 28(10): 973-981.

Mierzejewski, P. 1986. Ultrastructure, taxonomy and affinities of some Ordovician and Silurian microfossils. Palaeontologia Polonica 47: 129-220.

Mierzejewski, P., and C. Kulicki. 2001. Graptolite-like fibril pattern in the fusellar tissue of Palaeozoic rhabdopleurid pterobranchs. Acta Palaeontologica Polonica 46: 349-366.

Miller, M.A., and G.L. Williams. 1991. Ordovician chitinous hydroids from Hudson Strait, District of Franklin, Northwest Territorie. Atlantic Geology 27: 107-110.

Muscente, A.D. 2011. Paleoecology and other features of Plumalina incertae sedis. Geological Society of America Abstracts with Programs 43(5): 545.

Müller, A.H. 1978. Über Hydromedusen (Coelenterata) und medusoide Problematica aus dem Rotliegenden von Mitteleuropa. Freiberger Forschungsheft C342: 29-44.

Ossian, C.R. 1973. New Pennsylvanian scyphomedusan from western Iowa. Journal of Paleontology 47: 990-995.

Park, E., D.-S. Hwang, J.-S. Lee, J.-I. Song, T.-K. Seo, and Y.-J. Won. 2012. Estimation of divergence times in cnidarian evolution based on mitochondrial protein-coding genes and the fossil record. Molecular Phylogenetics and Evolution 62: 329-365.

Pushkin, V.I., and L.E. Popov. 1999. Early Ordovician bryozoans from north-western Russia. Palaeontology 42: 171-189.

Rickards, R.B., M.A. Hamedi, and A.J. Wright. 2001. A new assemblage of graptolites, rhabdopleuran hemichordates and chitinous hydroids from the late Arenig (Ordovician) of the Banestan area, east-central Iran. Alcheringa 25: 169-190.

Romero, A., R.R. Rogers, and L.A. Gershwin. 2011. Medusoid cnidarians from the Montral-Alcover Lagerstätten (Triassic), northeastern Spain. Batalleria 16: 50-57.

Schram, F.R., and M.H. Nitecki. 1975. Hydra from the Illinois Pennsylvanian. Journal of Paleontology 49: 549-551.

Scrutton, C.T. 1975. Hydroid-serpulid symbiosis in the Mesozoic and Tertiary. Palaeontology 18: 255-274.
Shimizu, H., and H. Namikawa. 2009. The body plan of the cnidarian medusa: Distinct differences in positional origins of polyp tentacles and medusa tentacles. Evolution and Development 11: 619-621.

Stolarski, J., V.M. Kitahara, D. Miller, S.D. Cairns, M. Mazur, and A. Meibom. 2011. The ancient evolutionary origins of Scleractinia revealed by azooxanthellate corals. BMC Evolutionary Biology 11: 316. doi:10.1186/1471-2148-11-316.

Taylor, P.D. 1988. A probable thecate hydroid from the upper cretaceous of Southern England preserved by bioimmuration. Paläontologische Zeitschrift 62: 167-174.

Taylor, W.L., and D.H. Griffing. 1996. First occurrence of Plumalina incertae sedis in the Silurian. Geological Society of America Abstracts with Programs 28(7): 429.

Tretenichenko, E.M., V.M. Datsun, L.N. Ignatyuk, and L.A. Nud'ga. 2006. Preparation and properties of chitin and chitosan from a hydroid polyp. Russian Journal of Applied Chemistry 79: 1341-1346.

Urbanek, A., and P.N. Dilly. 2000. The stolon system in Rhabdopleura compacta (Hemichordata) and its phylogenetic implications. Acta Palaeontologica Polonica 45: 201-226.

Voigt, E. 1973. Hydrallmania graptolithiformis n. sp., eine durch Bioimuration erhaltene Sertulariidae (Hydroz.) aus der Mastrichter Tuffkreide. Paläontologische Zeitschrift 47: 25-31.

Waggoner, B.M., and M.R. Langer. 1993. A new hydroid from the upper cretaceous of mississippi. Paläontologische Zeitschrift 67: 253-259.

Wilson, M.A., and T.J. Palmer. 2006. Patterns and processes in the Ordovician bioerosion revolution. Ichnos 13: 109-112.

Wilson, M.A., T.J. Palmer, and P.D. Taylor. 1994. Earliest preservation of soft-bodied fossils by epibiont bioimmuration: Upper Ordovician of Kentucky. Lethaia 27: 269-270.

Young, G.A., and J.W. Hagadorn. 2010. The fossil record of cnidarian medusa. Palaeoworld 19: 212-221.

Zágoršek, K., P.D. Taylor, and R. Vodrážka. 2009. Coexistence of symbiotic hydroids (Protulophila) on serpulids and bryozoans in a cryptic habitat at Chrtníky (lower Turonian, Czech Republic). Bulletin of Geosciences 84: 631-636. 